\title{
Prioritization of Brand Equity Components Using an Integrated Structural Equation Modelling and Fuzzy AHP
}

\author{
Gelare Mortezaei, Hamidreza Alizadeh Otaghvar*, Hossein Vazifehdoost, Parviz Saeedi, Abdolaziz Pegheh
}

\begin{abstract}
Brand equity of health tourism is the set of assets (or liabilities) of the brand in relation to the name and symbol of the tourism destination that cause changes in the value of services and experiences that are determined there. Considering the characteristics and cultural, social and economic capacities of Iranian tourism destinations, this study tends to develop a model for brand equity in health tourism, derived from the Acker model, according to Iran's conditions and studies conducted. First, previous studies in this regard were carefully reviewed by meta-synthesis. Then the mixed method including qualitative and quantitative methods was applied. The data were analyzed using grounded theory and MAXQDA18 software and then using structural equation method and fuzzy Analytic Hierarchy Process (Fuzzy AHP). Statistical population included experts including professors in the field of marketing and health tourism specialists for qualitative part, and foreign users of health tourism services of Iran for quantitative part. The results showed that hospital brand equity is directly affected by brand awareness, brand association, perceived quality, brand loyalty, social responsibility, firm value and customer value. As a result, at the national level, investing in this sector and branding and paying attention to brand equity of health tourism can make Iran one of the best health tourism destinations in the world.
\end{abstract}

Keywords: Analytic Hierarchy Process (AHP); brand equity; fuzzy; grounded theory; structural equations

\section{INTRODUCTION}

A brand without awareness is just a word on the product. The goal of investing in advertising is to reveal the meaning of the brand and spread it as much as possible so that people can try the products offered. Aaker [1] defined brand awareness as the ability of potential buyers for recognition or recall of a brand of a particular product category. Brand awareness refers to the power of brand memory, that is, how easy it is for consumer to remember the brand. Brand recall is the most common method of evaluating brand awareness [2]. Keller [2] believes that brand awareness can increase tendency towards the brand as a part, a chosen form, and even a set of interest. Recognition refers to correct differentiation of a brand from other brands by customers and recall refers to ability to recover brand from memory when accompanied by a guide. There are a wide range of various brands on the market; on one hand, there are famous brands for consumers and, on the other hand, there are brands of which customers are less aware [3]. Customer-based brand equity occurs when the customer has a high level of awareness and closeness with the brand and keeps strong and unique brand associations in his mind [3]. Tourism industry, as one of the most diverse and largest industries in the world, is the most important source of income and job opportunities for many countries in the world. This industry is important in two main ways: first, it provides nations with familiarity with other cultures, races, ethnicities, lands, dialects, etc., and second, it is economically the source of income and currency. Development of tourism industry, in addition to having broad economic dimensions such as job creation, income generation, poverty reduction and increased welfare in society, also affects the expression of national identity and social security and expansion of social justice in society [4]. According to definition of the World Tourism Organization, one of the goals that encourages tourists to travel is to gain health. Currently, tourism has become so important in socioeconomic development of countries that economists have called it invisible exports. Tourism, as the third largest industry in the world, is very important. One of the potentials of tourism is travel for the purpose of treatment. Health and healthcare tourism has grown dramatically in recent years. Increased demand for health services due to aging population in developed countries, availability of quality and affordable medical services in developing countries compared to developed countries, long waiting lists for surgery in developed countries, and lack of health insurance are the most common factors for medical travel. Among the various fields of tourism, health tourism and its sub-sectors due to their competitive capabilities and advantages have received double attention and show rapid growth among the types of tourism [5]. The World Tourism Organization defines health tourism as the use of services that improve or enhance one's health and morale (by using mineral water, weather, or medical interventions) in a place outside one's residence and last more than 24 hours [5]. Health tourism includes people and groups who travel to take advantage of climate change (for medical and therapeutic purposes), to use mineral water, to recover, to undergo treatment, and so on. Many patients also go to important and reputable medical centers in developed countries or capitals of countries that benefit from health facilities for treatment. This type of tourism is very prestigious and popular. At the macro level, governments are interested in taking advantage of economic benefits of this industry. Currently, increasing competition has begun between different countries, especially developing Asian countries, to attract health tourists. On the other hand, health tourism has also flourished in developing countries. Globalization and liberalization of trade in the field of health services became the basis for rapid growth of this type of tourism. According to the studies conducted in the field of health tourism, this industry can be divided into three types: A) health tourism: travel to health villages and areas with mineral springs and hot water, to get rid of stresses of daily life and rejuvenate without medical intervention and supervision; B) medical tourism (rehabilitation): travel to use 
natural healing resources (such as mineral water, salt and sludge) to treat some diseases or to recover under medical supervision and intervention; C) medical tourism: travel to treat physical illnesses or perform a variety of surgical procedures under the supervision of physicians in hospitals and medical centers. In a study conducted by the United Nations, factors such as advanced facilities, high quality and low cost of treatment have been cited as the most important factors in attracting patients in the field of medical tourism.

According to Shabani and Taleghani [6], every tourist who enters the country creates jobs for three people; in medical tourism, doctors, nurses, etc. will be added to these three people. Every health tourist imports currency three times as much as an ordinary tourist. In the field of medical tourism, not only the tourist attraction is considered, but also medical tourism strengthens the position of the country in terms of science, politics, society and region. If health tourism is considered a priority, Iran can potentially prevent the outflow of currency and manpower to other countries. Iran has capabilities in this field such as recombinant drugs, stem cells, ophthalmic and cancers treatments, as well as low medical costs compared to European and American countries, low cost of accommodation compared to the Persian Gulf region, religious commonalities, proximity to the Arab market, similarity of culture and dialect with some neighboring countries and natural potentials such as climatic diversity as a four-season country, sludge therapy, sand therapy, mud volcanoes and hydrotherapy and existence of more than a thousand mineral springs and other natural attractions that have the necessary potential in the field of health tourism and particularly medical tourism. On the other hand, the benefits of health tourism can lead to economic development in our country, which is heavily dependent on oil revenues. In the perspective of the contemporary tourism industry, destination brand development has become a strategic tool worldwide due to the increasing competition of tourism destinations. A successful tourism brand can be very effective in increasing the competitive advantage of the destination, attracting tourists and as a result increasing the revenues from the tourism industry and prosperity of the national economy. The tourist destination brand can be used as a way to communicate the unique identity of the tourist destination by differences of that destination with its other competitors. In marketing, a brand is widely used for products and services. A tourist destination can also be considered as a product or a brand that contains tangible or intangible features. Although destination brand is a new concept, many tourism destinations around the world are trying to adopt brand strategies for their destinations, as manufacturers of goods do, in order to distinguish their identity from their competitors and emphasize the uniqueness of their products. Tourist destination brand can be used as a way to communicate the unique identity of the tourist destination by differences of that destination with its other competitors. In the past decade, the concepts of brand, reputation and social policy making have been widely used in national and international communities, urban and national tourism and economic development; currently, there are approximately 300 countries and administrative regions in the world, 3400 large cities regardless of their size, current reputation, trade centers and resources have faced competitive challenges in global marketing through development and adaptation or somehow management of national and international reputation. Destination reputation plays an important role in the tourism industry. A more popular destination will be more reliable and trustworthy than lesser-known destinations. Strong reputation has a positive effect on destination image, perceived value, destination loyalty and, ultimately, satisfaction [3]. The destination brand is more complex than the product brand and firm brand; because it is involved with a larger number of stakeholders in products, services, resources and even different sectors of the economy. Countries, cities or regions should express the benefits of traveling to that region and create a good image of it in the minds of tourists, rather than creating tourism infrastructure and offering the right products and services. They should also strive to improve the brand equity [7].

\section{THEORETICAL FOUNDATIONS}

As Clare believes, there are different definitions of brand equity that are generally considered from different perspectives. Brand equity can be discussed from the perspective of the manufacturer, retailer or customer. While manufacturers and retailers tend to engage in strategic brand equity functions, investors are increasingly interested in the defined financial concept. Advocates of the financial view define brand equity as total value of a brand that is a separate asset when it is sold or added to the balance sheet. Other definitions that agree with this view consider brand equity as cash flows that have an upward trend over time for branded goods versus non-branded goods. Brand equity is the value that a brand adds to a product. In general, brand equity is the consumer's perception of all the advantages that one brand has over other competing brands. Consumer-based brand equity is a strategic role and an important competitive advantage that is considered in strategic management decisions and has a great impact on marketing decisions. Keller defines brand equity as distinctive effect of brand knowledge on consumer response to brand marketing [2]. In general, brand equity is the consumer perception of all the advantages and superiority that a brand has compared to other competing brands. According to Aaker [8], brand equity represents the price difference that a strong brand attracts in its sales compared to a medium brand.

\subsection{Theoretical Framework for Evaluating Customer-Based Brand Equity}

Boo et al. [9] defines the brand equity of a tourist destination as follows: Brand assets or liabilities in relation to the name and symbol of the tourist destination that add value to the services and experiences provided there. According to a study conducted by Wang et al. [10], brand equity output was considered by consumers' preferences to buy that product compared to its competitors. As noted in the theoretical literature of the present study, brand equity is a multifaceted and complex concept; in this study, the most important items tested empirically have been considered. Among various models for evaluating brand equity, this study adopted the model developed by Konecnik Ruzzier 
[11], which has been experimentally tested. The following is a brief description of each of these factors and their associated hypotheses:

Tourist destination brand awareness: The purpose of tourist destination marketing is to increase awareness of the tourist destination by creating a unique brand. Aaker [1] considers brand awareness as the power of a potential buyer in recall and recognition that put the brand in certain categories of products. He introduced several levels of brand awareness, starting with brand recognition and ending with the dominant brand. The dominant brand is a condition in which the brand is the only name that is recalled in the mind of the consumer in that product category. In this study, brand awareness means the ability of potential tourists to recognize and recall the tourism brand of Yazd as a tourist destination.

Tourist destination brand image: By definition, brand image is "perceptions of the brand that are reflected in the mind of the consumer by brand associations." The brand image does not necessarily have to be objective or reflect reality. For example, a customer's image of the quality of restaurant food can be based on the service provided by its staff rather than an objective assessment of the taste of the food. Likewise, the sun and the waves are reminiscent of Queensland.

Perceived quality: Perceived quality is defined as "consumer perception of the overall quality or superiority of a product or service over other options" [12]. Perceived quality is a competitive necessity, and today most companies are turning to customer-based quality as a strategic weapon [3]. In fact, perceived quality is not the real quality of the product, but the customer's mental evaluation of the product [12]. Like the brand image, perceived quality provides value to customers so that they have a reason to buy by differentiating the brand from competitors.

A study of past research on development of tourist destinations shows that only a few limited studies have examined perceived quality. This seems interesting because the overall evaluation of tourists from a destination is actually a combination of products, services and experiences. In all of these examples, quality plays a vital role in influencing consumer behavior. Because the tourism product is a service product, it is used to measure the perceived quality of the quality level. Parasuraman [13], by psychometric test and examining the common traits and characteristics of service quality, introduced five broad dimensions of service quality as follows: 1) perceptible factors of physical and tangible environment; 2) reliability; 3) accountability and assistance to customers; 4) guarantee of responsibility; 5) empathy.

Tourist destination brand loyalty: Although the concept of loyalty has been extensively studied in public marketing literature, brand loyalty in the form of tourist destinations has rarely been studied. It should be noted that loyalty increases the stability of the destination and advantages of brand loyalty for destinations include lower marketing costs, increased influence of travel business and repetition of wordof-mouth advertising. In their study, Pike [14] point out five factors that lead to a return to a destination already visited: 1 ) reduced risk of an unsatisfactory experience; 2) awareness that they are meeting people like themselves at that destination; 3) emotional attachment; 4) an opportunity to visit aspects of the destination that they have not experienced before; 5) showing others that their previous experience has been satisfactory.

\section{LITERATURE REVIEW}

Imani Yazdi and Ayoobi Yazdi [15] conducted a study on effective factors on brand equity in tourism in Yazd. The results of this study show that studies of the last thirty years considered it as the most important factor in evaluating the tourism destination brand by tourists. Brand loyalty, perceived quality, and tourism destination brand awareness also have a direct impact on brand equity of Yazd and loyalty is the most important effective factor.

Kotsi et al. [16] studied customer-centric brand equity in the context of an international stop destination: Dubai, on the way to France, Australia" and investigated the destination brand equity indicators and the reasons for choosing the destination. Liu et al. [17], using customer-based brand equity of luxury hotels, examined the elements of customercentric brand equity of luxury hotels. Sam Liu and Chou [18] studied sustainable tourism development and promotion of adaptation process of brand equity, marketing and motivation and ways to identify ways of sustainable tourism development through brand equity dimensions.

Chahal and Bala [19] studied important elements of service equity in the health sector and introduced three variables, perceived quality, brand loyalty, and image, as the most important effective factors on service brand equity and examined the relationship between these variables and their effect on service brand equity in the health sector. The data was collected from 602 native respondents in India. The findings show that brand equity in health services is strongly influenced by brand loyalty and perceived quality. In addition, the perceived quality is effective on brand image, while brand image indirectly through brand loyalty is effective on brand equity (brand loyalty is mediator). Sarker et al. [26] developed service-branding theory by theorizing and confirming a customer-oriented service brand equity in airline service industry. Guo and Zhou [27] studied the effect of brand awareness, brand association, perceived quality, and customer satisfaction on customer-based brand equity in China mobile phone industry.

\section{MAIN QUESTION}

How are brand equity components in health tourism prioritized?

\section{MATERIALS AND METHODS}

In this study, first, the qualitative research method is used to present the model and then the quantitative research method is used to test the model. This study used a mixed exploratory research design. In the first phase, the model was extracted using the model of Strauss and Corbin [20], qualitative method of grounded theory, and it was tested using quantitative tools in the next phase. 


\subsection{Grounded Theory}

Grounded theory was first proposed in 1967 by Glaser and Strauss. Strauss and Corbin [20] define grounded theory as follows: grounded theory is what is inductively derived from the study of a phenomenon and represents that phenomenon. That is, the theory is discovered, developed, and validated through systematic collection and analysis of data. Thus, data collection, analysis, and theory are in a reciprocal, two-way relationship. The ultimate goal of grounded theory is to provide comprehensive theoretical explanations of a particular phenomenon. In general, this strategy converts data from information resources into a set of codes, common codes into categories, and then categories into theory.

\subsection{Data Analysis}

As grounded theory was used, qualitative data analysis and paradigm model (regular or systematic design) were used. The regular design of grounded theory emphasizes the use of data analysis steps through open coding, axial coding, and selective coding, as well as presentation of a logical paradigm or visual representation of an evolving theory. Qualitative data analysis was performed with grounded theory and with the help of MAXQDA18 software, and as a result, the final model was extracted. This model was sent back to experts for review and approval and was approved by them. Fig. 1 shows the conceptual model of the study.

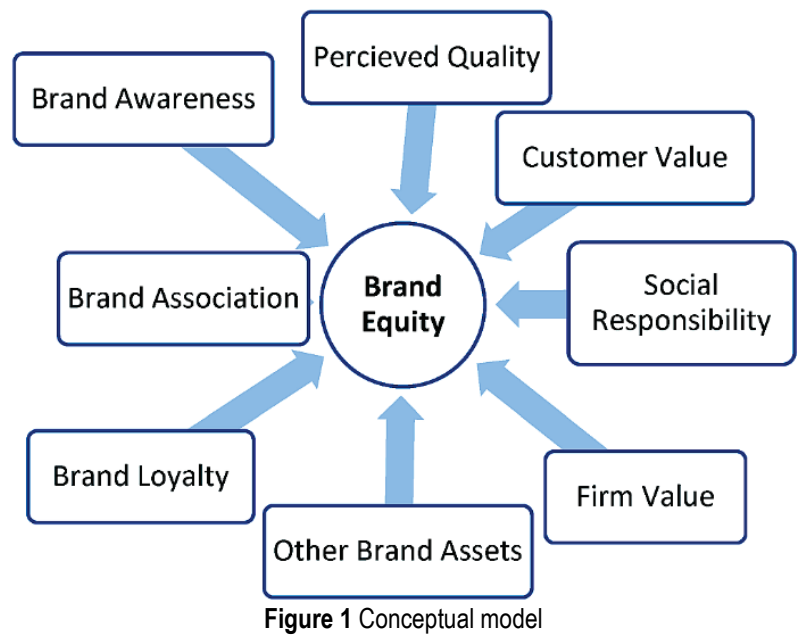

\subsection{Statistical Population}

In the first phase, the statistical population consists of experts to the research topic. The conditions for certification of members were a strong scientific or experimental insight into the phenomenon, i.e. brand equity in health tourism. In order to benefit from opinions of experts who have scientific insight, professors of marketing and tourism and practitioners in the field of health tourism, as well as consultants and managers in this field who have a scientific and experimental background consist the statistical population. In this part, 22 marketing professors and health tourism specialists were interviewed, which was used to reach theoretical saturation.

In quantitative part, foreign patients who have used health tourism services in our country's hospitals and medical centers consist the statistical population. The questionnaire was distributed among 400 people and the number of healthy questionnaires was 380 , which were quantitatively processed.

\section{DATA ANALYSIS}

A questionnaire was developed based on what was obtained from the qualitative part and was given to 400 foreign patients using medical services and finally 380 questionnaires were identified as healthy and processed by structural equation method and using SmartPLS software. The results are shown in Tab. 1. As can be seen, there is a significant relationship between stages of prioritization of brand equity components in health tourism with fuzzy AHP technique [21, 22], as follows:

\subsection{Obtaining Component Weight by Fuzzy Analytic Hierarchy Process}

\section{1) Build a decision hierarchy tree}

The first step in analytic hierarchy process begins with developing a decision hierarchy tree.

The levels of the decision hierarchy tree are:

First level (general goal): Prioritization of brand equity components in health tourism

Second level (criteria): 1) Perceived quality, 2) Creating value for the customer, 3) Other brand assets, 4) Brand association, 5) Social responsibility, 6) Brand awareness, 7) Brand loyalty, 8) Creating value for the organization;

Third level (sub-criteria): quality of hospitals, quality of medical staff, quality of up-to-date medical equipment, number and variety of medical centers, perceived quality of the country's brand, accountability, trust in customer purchasing decisions, consumer satisfaction, stakeholder interests, customer information process, treatment and traditional medicine, interaction with international medical organizations, applying ideas and opinions, paying attention to Iran's potential, managing activities and resources, the country's brand association, word of mouth, multimedia advertising, existence of relational channels, social accountability, communication with medical staff, attention to the environment, the country brand image, urban management in Iranian cities, geographical location, brand loyalty, hospitality, philanthropy of the medical staff, continuous evaluation of patients, advice to others, effectiveness and efficiency of the marketing program, brand development, competitive advantage, prices and profit margins.

2) Pairwise comparisons and calculation of the weight of variables

In this section, we can compute the weights of pairwise comparison matrix by Chang's method [25]. Respondents are asked to evaluate the importance of each factor in pairs. In fact, people's opinions are combined with each other after 
completing the questionnaires. Next, to determine consistency or inconsistency of the judgments, it is necessary to calculate the inconsistency rate of each individual's judgment matrix.

$\tilde{t}_{i j}=(a, b, c)$

Using the decision maker's judgment, a comparison matrix (Eq. (2)) is formed using triangular fuzzy numbers based on judgments of several decision makers.

In this matrix, $p_{i j}$ is the number of people judging the priority of element $i$ over $j$.

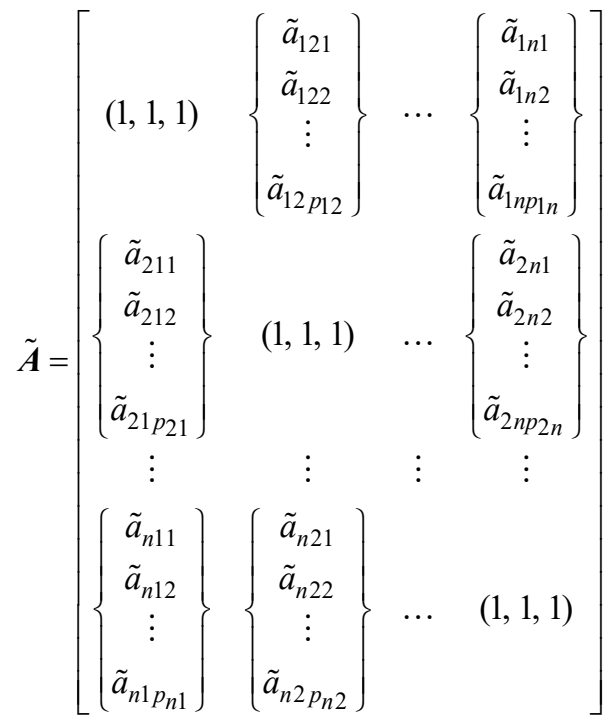

Table 1 Factor loading

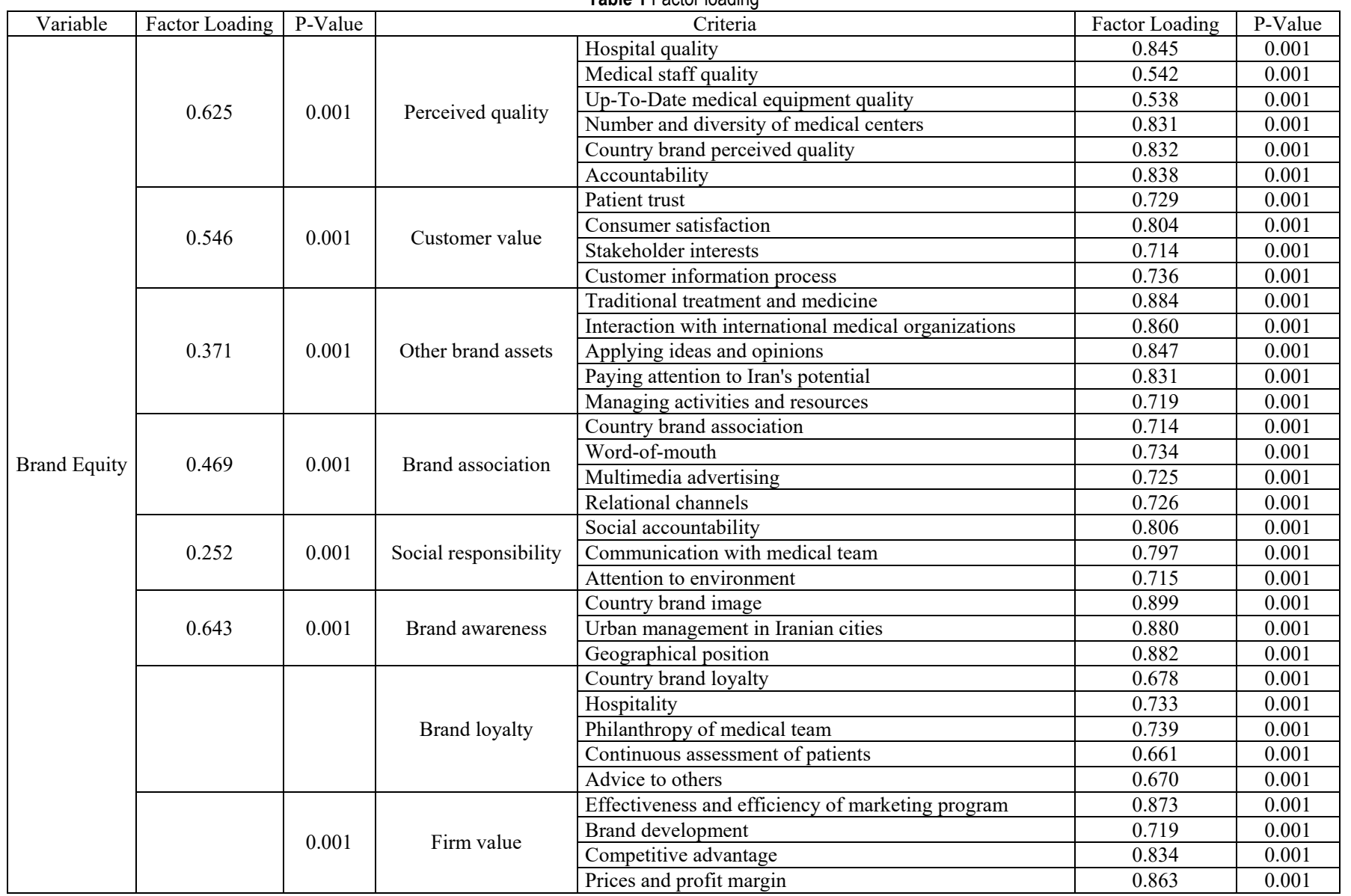

3) Arithmetic mean of judgments: Arithmetic mean of decision-makers' judgment is calculated as the following matrix:

$$
\tilde{\boldsymbol{A}}=\left[\begin{array}{cccc}
1 & \tilde{a}_{12} & \ldots & \tilde{a}_{1 n} \\
1 / \tilde{a}_{12} & 1 & \ldots & \tilde{a}_{2 n} \\
\vdots & \vdots & \ddots & \vdots \\
1 / \tilde{a}_{1 n} & 1 / \tilde{a}_{2 n} & \ldots & 1
\end{array}\right]
$$

Arithmetic mean of decision-makers' judgments

$$
\tilde{a}_{i j}=\frac{\sum_{k=1}^{p_{i j}} a_{i j k}}{p_{i j}} \quad i, j=1,2, \ldots, n
$$

4) Calculation of the sum of row elements: The sum of row elements is calculated: 
$\tilde{s}_{i}=\sum_{j=1}^{n} \tilde{a}_{i j} \quad i=1,2, \ldots, n$

5) Normalization: The sum of rows is normalized as follows:

$\tilde{M}_{i}=\tilde{s}_{i} \otimes\left[\sum_{i=1}^{n} \tilde{s}_{i}\right]^{-1} \quad i=1,2, \ldots, n$

Let show $\tilde{s_{i}}$ as $\left(l_{i}, m_{i}, u_{i}\right)$; the Eq. (7) is calculated as:

$\tilde{M}_{i}=\left(\frac{l_{i}}{\sum_{i=1}^{n} u_{i}}, \frac{m_{i}}{\sum_{i=1}^{n} m_{i}}, \frac{u_{i}}{\sum_{i=1}^{n} l_{i}}\right)$

6) Determining the degree of probability of being larger: We calculate the degree of probability that each $\mu_{i}$ is larger than the other $\mu$ is and call it $d^{\prime}\left(A_{i}\right)$.

The degree of probability that the fuzzy triangular number $\mu_{2}=\left(l_{2}, m_{2}, u_{2}\right)$ is larger than the fuzzy triangular number $\mu_{1}=\left(l_{1}, m_{1}, u_{1}\right)$ is equal to:

$V\left(M_{2}>M_{1}\right)=\operatorname{Sub}_{y \geq x}\left[\min \left(\mu_{M_{1}}(x), \mu_{M 2}(y)\right)\right]$

This relation can be synonymously expressed as follows:

$V\left(M_{2} \geq M_{1}\right)=\operatorname{hgt}\left(M_{1} \cap M_{2}\right)=\mu_{M_{2}}(d)=$

$= \begin{cases}1 & \text { if } m_{2} \geq m_{1} \\ 0 & \text { if } l_{1} \geq u_{2} \\ \frac{l_{1}-u_{2}}{\left(m_{2}-u_{2}\right)-\left(m_{1}-l_{1}\right)}, & \text { Otherwise }\end{cases}$

where, $d$ is coordinates of the highest point in the communality region and collision of two membership functions $\mu_{M_{1}}$ and $\mu_{M_{2}}$.

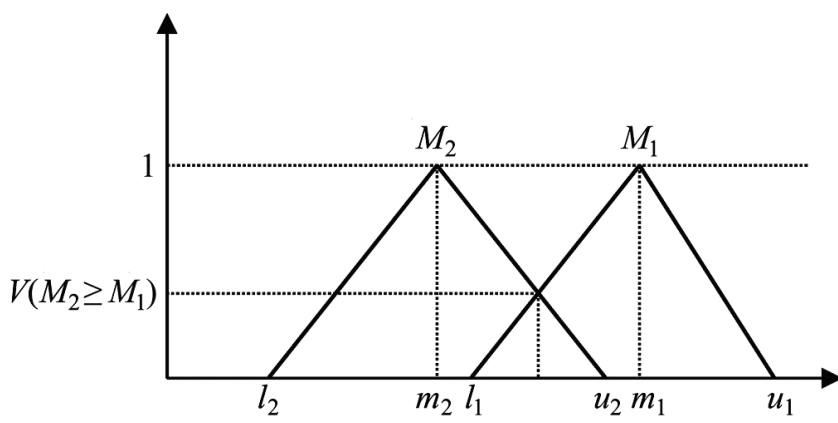

Figure 2 Prioritization of two triangular fuzzy numbers

To compare $M_{1}$ and $M_{2}$, it is necessary to calculate both $V\left(M_{2} \geq M_{1}\right)$ and $V\left(M_{1} \geq M_{2}\right)$ (Fig. 2). The degree of probability that a convex fuzzy number $(M)$ is greater than another $K$ convex fuzzy number $\left(M_{i} ; i=1,2, \ldots, k\right)$ is divided as follows:

$d^{\prime}(M)=V\left(M \geq M_{1}, M_{2}, \ldots, M_{k}\right)=$

$=V\left[\left(M \geq M_{1}\right),\left(M \geq M_{2}\right), \ldots,\left(M \geq M_{k}\right)\right]=$

$=\min V\left(M \geq M_{i}\right)$

7) Normalization: By normalizing the weight vector, normalized weights are obtained.

$\boldsymbol{w}=\left[\frac{d^{\prime}\left(A_{1}\right)}{\sum_{i=1}^{n} d^{\prime}\left(A_{i}\right)}, \frac{d^{\prime}\left(A_{2}\right)}{\sum_{i=1}^{n} d^{\prime}\left(A_{i}\right)}, \ldots, \frac{d^{\prime}\left(A_{n}\right)}{\sum_{i=1}^{n} d^{\prime}\left(A_{n}\right)}\right]^{\mathrm{T}}$

The above weights are definite (non-fuzzy) weights. By repeating this process, the weights of all matrices are obtained.

8) Composition of weights: By combining the option weights and the criteria, the final weights are obtained.

$\tilde{U}_{i}=\sum_{j=1}^{n} \tilde{w}_{i} \tilde{r}_{i j} \quad \forall i$

In fact, after completing the questionnaires, people's judgments are combined with each other. Next, to determine consistency or inconsistency of the judgments, it was necessary to calculate the inconsistency rate of the judgment matrix of each person.

In order to achieve this goal, questionnaires of pairwise comparisons were designed and distributed among experts. According to fuzzy approach in this study, corresponding verbal expressions and evaluation of indicators and subindicators relative to each other (for pairwise comparisons) in Tab. 2 were used.

Table 2 Fuzzy spectrum and corresponding verbal expressions

\begin{tabular}{|c|l|c|}
\hline Code & \multicolumn{1}{|c|}{ Verbal expression } & Fuzzy number \\
\hline 1 & Absolutely equal preference & $(1,1,1)$ \\
\hline 2 & Approximately equal preference & $(0.5,1,1.5)$ \\
\hline 3 & Low preference & $(1,1.5,2)$ \\
\hline 4 & High preference & $(1.5,2,2.5)$ \\
\hline 5 & Very high preference & $(2,2.5,3)$ \\
\hline 6 & Absolutely high preference & $(2.5,3,3.5)$ \\
\hline
\end{tabular}

The scale used in this study is a 6-item fuzzy scale based on the modified method of Saaty [23].

\section{3) Consistency of judgments}

The following steps are used to calculate the inconsistency rate:

Step 1. Calculate the total weight vector: Multiply the pairwise comparison matrix $(\boldsymbol{D})$ by the column "Relative Weight" $(W)$. The new vector obtained this way is called the total weight vector.

$\boldsymbol{W S} \boldsymbol{V}=\boldsymbol{D} \times W$ 
Step 2. Calculate the consistency vector: Divide the elements of total weight vector by relative priority vector. The resulting vector is called the consistency vector.

Step 3. Obtaining $\lambda_{\max }$ gives the average of $\lambda_{\max }$ consistency vector elements.

$C I=\frac{\lambda_{\max }-n}{n-1}$

where, $n$ implies the number of options in the problem.

Step 4. Calculate the consistency index: The consistency index is defined as follows:

$$
C I^{g}=\frac{\left(\lambda_{\max }^{g}-n\right)}{(n-1)}
$$

Step 5. Calculate the consistency ratio: The consistency ratio is obtained by dividing the consistency index by a random index.

$$
C R=\frac{C I}{C R}
$$

Consistency ratio of 0.1 or less expresses consistency in comparisons.

\subsection{Analysis of Results in Calculations of Pairwise Comparison Matrices and Inconsistency Rate}

The calculations of all pairwise comparison matrices as well as inconsistency rate and analysis and results are presented in Tab. 3. Ranking of these factors are shown in Tab. 4. The order of prioritization is as Brand awareness, Firm value creation, Brand association, Perceived quality, Social responsibility, Customer value creation, Brand

\begin{tabular}{|c|c|c|c|c|c|c|c|c|}
\hline $\begin{array}{l}\text { Brand equity in health } \\
\text { tourism }\end{array}$ & $\begin{array}{l}\text { Perceived } \\
\text { quality }\end{array}$ & $\begin{array}{l}\text { Customer value } \\
\text { creation }\end{array}$ & $\begin{array}{l}\text { Other brand } \\
\text { assets }\end{array}$ & $\begin{array}{c}\text { Brand } \\
\text { association }\end{array}$ & $\begin{array}{c}\text { Social } \\
\text { responsibility }\end{array}$ & Brand awareness & Brand loyalty & $\begin{array}{l}\text { Organization } \\
\text { value }\end{array}$ \\
\hline Perceived quality & $(1,1,1)$ & $\begin{array}{c}(0.707,1.225 \\
1.732) \\
\end{array}$ & $(1.5,2,2.5)$ & $(0.667,1,2)$ & $(1,1.5,2)$ & $(0.333,0.4,0.5)$ & $(1,1.5,2)$ & $(0.5,0.667,1)$ \\
\hline $\begin{array}{l}\text { Customer value } \\
\text { creation }\end{array}$ & $\begin{array}{c}(0.577,0.816, \\
1.414)\end{array}$ & $(1,1,1)$ & $\begin{array}{c}(1.225,1.732, \\
2.236)\end{array}$ & $\begin{array}{c}(0.447,0.577, \\
0.816)\end{array}$ & $(0.5,1,1.5)$ & $\begin{array}{c}(0.365,0.447, \\
0.577)\end{array}$ & $(0.5,1,1.5)$ & $(0.447,0.707,1)$ \\
\hline Other brand assets & $\begin{array}{c}(0.4,0.5 \\
0.667) \\
\end{array}$ & $\begin{array}{c}(0.447,0.577, \\
0.816)\end{array}$ & $(1,1,1)$ & $\begin{array}{c}(0.447,0.577, \\
0.816)\end{array}$ & $(0.667,1,2)$ & $(0.286,0.333,0.4)$ & $(1,1,1)$ & $(0.333,0.4,0.5)$ \\
\hline Brand association & $(0.5,1,1.5)$ & $\begin{array}{c}(1.225,1.732, \\
2.236) \\
\end{array}$ & $\begin{array}{c}(1.225,1.732, \\
2.236) \\
\end{array}$ & $(1,1,1)$ & $\begin{array}{c}(0.707,1.225, \\
1.732) \\
\end{array}$ & $(0.5,0.667,1)$ & $(1,1.5,2)$ & $(0.667,1,2)$ \\
\hline Social responsibility & $(0.5,0.667,1)$ & $(0.667,1,2)$ & $(0.5,1,1.5)$ & $\begin{array}{c}(0.577,0.816 \\
1.414)\end{array}$ & $(1,1,1)$ & $\begin{array}{c}(0.447,0.577, \\
0.816)\end{array}$ & $\begin{array}{c}(1.225,1.414, \\
1.581)\end{array}$ & $\begin{array}{c}(0.516,0.707, \\
1.155)\end{array}$ \\
\hline Brand awareness & $(2,2.5,3)$ & $\begin{array}{l}(1.732,2.236, \\
2.739)\end{array}$ & $(2.5,3,3.5)$ & $(1,1.5,2)$ & $\begin{array}{l}(1.225,1.732, \\
2.236)\end{array}$ & $(1,1,1)$ & $\begin{array}{l}(1.414,1.936, \\
2.449)\end{array}$ & $(0.5,1,1.5)$ \\
\hline Brand loyalty & $(0.5,0.667,1)$ & $(0.667,1,2)$ & $(1,1,1)$ & $(0.5,0.677,1)$ & $\begin{array}{l}(0.632,0.707, \\
0.816)\end{array}$ & $\begin{array}{l}(0.408,0.516 \\
0.707)\end{array}$ & $(1,1,1)$ & $(0.333,0.4,0.5)$ \\
\hline Firm value creation & $(1,1.5,2)$ & $(1,1.414,2.236)$ & $(2,2.5,3)$ & $(0.5,2,1.5)$ & $\begin{array}{l}(0.866,1.414, \\
1.936)\end{array}$ & $(0.667,1,2)$ & $(2,2.5,3)$ & $(1,1,1)$ \\
\hline
\end{tabular}
loyalty, and other brand assets.
Table 4 Mean of pairwise comparisons to brand equity in health tourism

\begin{tabular}{|l|c|c|c|}
\hline \multicolumn{1}{|c|}{ Criteria } & Geometric mean & $\begin{array}{c}\text { Final } \\
\text { weight }\end{array}$ & Rank \\
\hline Perceived quality & $(0.765,1.0491,1.428)$ & 0.137 & 4 \\
\hline Customer value creation & $(0.581,0.8441,1.163)$ & 0.11 & 6 \\
\hline Other brand assets & $(0.517,0.621,0.806)$ & 0.081 & 8 \\
\hline Brand association & $(0.805,1.177,1.6391)$ & 0.153 & 3 \\
\hline Social responsibility & $(0.637,0.865,1.259)$ & 0.116 & 5 \\
\hline Brand awareness & $(1.286,1.741,2.159)$ & 0.218 & 1 \\
\hline Brand loyalty & $(0.588,0.71,0.934)$ & 0.093 & 7 \\
\hline Firm value creation & $(1.018,1.442,1.977)$ & 0.188 & 2 \\
\hline
\end{tabular}

\section{DISCUSSION}

In grounded theory, the process of data collection and interpretation should both be evaluated and validated as research findings. Internal validity is defined as: "Internal validity deals with the question of how do research findings match facts?" The question is whether what has been studied and found is what really exists and what researchers observe is what they think has been measured. To strengthen the internal validity of qualitative research, Merriam [24] has suggested the following:

- Pluralism: Several researchers, multiple data sources, or multiple methods are used to validate emerging data.
- Member review: Ask respondents if the results are acceptable.

- Long-term observation of research site or repetitive observations of similar phenomenon: Data is collected over a period with the aim of increasing the validity of the findings.

- Pairwise review: Ask colleagues to note on emerging findings.

- Elimination of prejudices: At the beginning of the research, the researcher should identify the assumptions, theoretical tendencies and prejudices and prevent them from interfering in the research process.

This study used triangular methods, member reviews and pairwise review for internal increase.

As observed, there is a significant relationship between brand equity and brand awareness, brand association, perceived quality, brand image, brand loyalty, firm value, customer value and social responsibility. By improving and developing these dimensions, which we examined in the analysis, we can offer a health tourism brand equity for Iran and promote it to take the best advantage of this profitable industry considering the many facilities and capacities in the 
country, including natural and historical attractions, tourism facilities, medical facilities, experienced doctors and paramedics that now exist in the country. Considering that most of the neighbouring countries, which are very culturally close to us, do not have such facilities in their country, we can take the best advantage of this favorable situation and introduce our country as one of the best health tourism centers, while creating employment and bringing currency for our country and reach sustainable development of this industry so that we can become one of the best health tourism destinations in the world in the near future.

\section{CONCLUSION}

As it is obvious, there is a relationship between brand equity and brand awareness, brand association, brand loyalty, customer value, other firm assets, social responsibility and firm value. In the meantime, it can be seen that health tourism brand equity is most affected by dimensions of brand awareness, brand association, and other brand assets. In addition, we see that firm value itself is affected by brand development, competitive advantage, price and profit margin, and effectiveness of the marketing program. Moreover, social responsibility is related to social accountability, communication with medical staff and attention to the environment. Customer value is also related to customer information, patient trust, consumer satisfaction, and stakeholder interests. Brand awareness is also affected by brand position, country brand image and urban management. Perceived quality is also related to hospital quality, medical staff quality, medical equipment, variety of medical centers, perceived quality and accountability. Brand loyalty depends on country brand loyalty, hospitality, philanthropy of the medical staff, continuous evaluation of patients, and brand loyalty. Brand association is related to association of the country brand, word of mouth, multimedia advertising and relational channels.

\section{Acknowledgement}

Thanks to all the respected professors who helped us in this research.

\section{REFERENCES}

[1] Aaker, D. A. (1991). Managing Brand Equity: Capatilizing on the Value of a Brand Name. Free Press, New York

[2] Keller, K. L. (1993). Conceptualizing, measuring, and managing customer-based brand equity. Journal of Marketing, 57(1), 1-22. https://doi.org/10.1177/002224299305700101

[3] Atilgan, E., Aksoy, Ş., \& Akinci, S. (2005). Determinants of the brand equity: A verification approach in the beverage industry in Turkey. Marketing Intelligence \& Planning, 23(3). https://doi.org/10.1108/02634500510597283

[4] Firoozjaian, A. A., Firoozjaian, M., Hashemi petroodi, S. H., \& Gholamrezazadeh, F. (2012). Using of Interpretive modeling in Tourism Studies. Journal of Tourism Planning and Development, 6(1), 129-159.
[5] Haghighi Kafash, M. \& Jafari, Gh. (2006). Prioritize of factors in Iran medical Tourism. Tourism Studies Journal, 11, 23-41.

[6] Shabani, A. \& Taleghani, M. (2013). Effect of Experience and satisfaction of tourists for returning. Journal of Geography and Environmental Studies, 2(1), 55-64.

[7] Dehdashti, Z., Harandi, A., \& Sedghiani, J. (2015). Effect of Brand Equity for hotel customers. Tourism Management Studies Journal, 5(71), 1-23.

[8] Aaker, D. A. (1996). Measuring brand equity across products and markets. California Management Review, 38(3). https://doi.org/10.2307/41165845

[9] Boo, S., Busser, J., \& Baloglu, S. (2009). A model of customerbased brand equity and its application to multiple destinations. Tourism Management, 30(2), 219-231. https://doi.org/10.1016/j.tourman.2008.06.003

[10] Wang, H., Wei, Y., \& Yu, C. (2008). Global brand equity model: combining customer-based with product-market outcome approaches. Journal of Product \& Brand Management, 17(5). https://doi.org/10.1108/10610420810896068

[11] Konecnik, M. (2002). The image as a possible source of competitive advantage of the destination - The case of Slovenia. Tourism Review. https://doi.org/10.1108/eb058373

[12] Zeithaml, V. A. (1988). Consumer perceptions of price, quality, and value: a means-end model and synthesis of evidence. Journal of marketing, 52(3), 2-22. https://doi.org/10.1177/002224298805200302

[13] Parasuraman, A., Berry, L. L., \& Zeithaml, V. A. (1993). More on improving service quality measurement. Journal of retailing, 69(1), 140-147. https://doi.org/10.1016/S0022-4359(05)80007-7

[14] Pike, S. (2004). Destination brand positioning slogans-towards the development of a set of accountability criteria. Acta Turistica, 16(2), 102-124.

[15] Imani Yazdi, M. H. \& Ayoobi Yazdi, H. (2014). Affecting factors on Brand Equity in Yazd. Tourism Management Studies Journal, 13, 137-113.

[16] Kotsi, F., Pike, S., \& Gottlieb, U. (2018). Consumer-based brand equity (CBBE) in the context of an international stopover destination: Perceptions of Dubai in France and Australia. Tourism Management, 69, 297-306. https://doi.org/10.1016/j.tourman.2018.06.019

[17] Liu. M. T., Wong, I. A., Tseng, T. H., Chang, A. W., \& Phau, I. (2017). Applying consumer-based brand equity in luxury hotel branding. Journal of Business Research, 81, 192-202. https://doi.org/10.1016/j.jbusres.2017.06.014

[18] Liu, C. H. S. \& Chou, S. F. (2016). Tourism strategy development and facilitation of integrative processes among brand equity, marketing and motivation. Tourism Management, 54, 298-308. https://doi.org/10.1016/j.tourman.2015.11.014

[19] Chahal, H. \& Bala, M. (2012). Significant components of service brand equity in healthcare sector. International Journal of Health Care Quality Assurance, 25(4), 343-362. https://doi.org/10.1108/09526861211221518

[20] Strauss, A. L. (1987). Qualitative analysis for social scientists. Cambridge University Press. https://doi.org/10.1017/CBO9780511557842

[21] Nazari-Shirkouhi, S., Mousakhani, S., Tavakoli, M., Dalvand, M. R., Šaparauskas, J., \& Antuchevičienè, J. (2020). Importance-performance analysis based balanced scorecard for performance evaluation in higher education institutions: an integrated fuzzy approach. Journal of Business Economics and Management, 21(3), 647-678. https://doi.org/10.3846/jbem.2020.11940 
[22] Keramati, A., Samadi, H., \& Nazari-Shirkouhi, S. (2013). Managing risk in information technology outsourcing: an approach for analysing and prioritising using fuzzy analytical network process. International Journal of Business Information Systems, 12(2), 210-242. https://doi.org/10.1504/IJBIS.2013.052052

[23] Saaty, T. L. (2009). Applications of analytic network process in entertainment. Iranian Journal of Operations Research, 1(2), 41-55.

[24] Merriam, S. B. (1988). Case study research in education: A qualitative approach. Jossey-Bass.

[25] Chang, D. Y. (1996). Application of extend analysis method on Fuzzy AHP. European Journal of Operational Research, 96, 343-350.

[26] Sarker, M., Mohd-Any, A. A., \& Kamarulzaman, Y. (2021). Validating a consumer-based service brand equity (CBSBE) model in the airline industry. Journal of Retailing and Consumer Services, 59, 102354.

https://doi.org/10.1016/j.jretconser.2020.102354

[27] Guo, W., \& Zhou, L. (2021). Influence factors of customerbased brand equity: A study on China mobile phone industry. International Journal of Financial Engineering, 8(01), 2050050.

\section{Authors' contacts:}

Gelare Mortezaei, PhD student in Marketing Management

Aliabad Katoul Branch, Islamic Azad University,

University blvd, Aliabad Katoul, 49417-93451, Iran

Hamidreza Alizadeh Otaghvar, Associate Professor of Plastic Surgery

(Corresponding author)

Trauma and Injury Center, Iran University of Medical Sciences,

Rasoul Akram Hospital, Niyayesh St, Sattarkhan St,

Tehran, 1445613131, Iran

halizadehotaghvar@chmail.ir

Hossein Vazifehdoost, Professor

Science and Research Branch, Islamic Azad University,

Daneshgah Blvd, Simon Bulivar Blvd, Tehran, 1477893855, Iran

Parviz Saeedi, Associate Professor

Aliabad Katoul Branch, Islamic Azad University,

University blvd, 49417-93451 Aliabad Katoul, Iran

Abdolaziz Pegheh, Assistant Professor

Aliabad Katoul Branch, Islamic Azad University,

University blvd, 49417-93451 Aliabad Katoul, Iran 